\title{
The Effect of Bribery on Firm Innovation: An Analysis of Small and Medium Firms in Vietnam*
}

\author{
Toan Ngoc NGUYEN ${ }^{1}$
}

Received: March 05, 2020 Revised: March 15, 2020 Accepted: April 03, 2020

\begin{abstract}
This study aims to provide empirical evidence on the causal relationship between bribery and firm innovation. To this end, we use a micro-dataset of small and medium firms in Vietnam surveyed in 2015. Given the binary nature of the dependent variable, a simple probit regression model is employed. However, as bribery variable is potentially endogenous, a simple probit regression may give biased estimates. We deal with the potential endogeneity by making use of the bivariate probit model. A property of the bivariate probit model is that it can produce efficient estimates of a typical probit model with endogenous binary explanatory variable. A Hausman-like likelihood ratio test is implemented following the estimation to test the existence of endogeneity. We find that bribery significantly undermines firm innovation. Also, firms run by household appear less innovative. The probability of innovation diminishes significantly if firm owners or managers have previous experience in firm products. As expected, larger firms seem to be more innovative. Exporters tend to be more innovative compared to non-exporters. Our findings provide support to the hypothesis that bribery is detrimental to firm innovation and, thus, innovation may be a mediating channel, through which, bribery impedes firm long-term performance.
\end{abstract}

Keywords : Bribery, Bivariate Probit Model, Firm Innovation, Sand the Wheels, Vietnam

JEL Classification Code: D22, D73, O31

\section{Introduction}

Innovation is vital to firm competitiveness and longterm development as well as national economic growth (Audretsch, 1995; Chiu \& Lin, 2019). It can take several forms, such as introducing new products, new production processes, technologies, or improving existing ones. However, in the context of widespread corruption in many developing countries, bribery and corrupt public officials

\footnotetext{
* The author would like to thank the World Institute for Development Economic Research, United Nations University (UNU-WIDER) for making available the data of CIEM, ILSSA, UCPH, and UNU-WIDER (2013 and 2015) Vietnam SME Surveys, which are used in this research.

${ }^{1}$ First Author and Corresponding Author. Lecturer, Institute of Economics, Ho Chi Minh Academy of Politics, Vietnam [Postal Address: No. 135, Nguyen Phong Sac Street, Cau Giay District, Hanoi, 113000, Vietnam] Email: toankyoto@gmail.com

(c) Copyright: The Author(s)

This is an Open Access article distributed under the terms of the Creative Commons Attribution Non-Commercial License (http://Creativecommons.org/licenses/by-nc/4.0/) which permits unrestricted noncommercial use, distribution, and reproduction in any medium, provided the original work is properly cited.
}

may affect firm innovation. It is argued that innovative firms may be more susceptible to bribery. Ayyagari, DemirgüçKunt, and Maksimovic (2014) found that innovative firms pay more bribes than non-innovators across 25,000 firms in 57 countries. They stressed that innovative firms tend to be victims of corrupt officials instead of strategically engaging in bribing behaviors. Understanding the effect of bribery on firm innovation is, therefore, important to facilitate firm innovation in developing countries.

There is, however, a paucity of theories and empirical evidence that adequately address the relationship between bribery and innovation (Habiyaremye \& Raymond, 2018; James, Leiblein, \& Lu, 2013). The vast literature often discusses the relationship between bribery and firm innovation in the broader context of bribery and firm performance. Some authors argued that bribery hurts firm performance because it undermines firm innovation and encourages rent-seeking behaviors (Murphy, Shleifer, \& Vishny, 1991). Others find that that bribery helps firm performance, including firm innovation, by clearing bureaucratic obstacles and hedging against political risks (Leff, 1964). As this literature is inconclusive, it is also disputable about how bribery would affect firm innovation. 
This study aims to examine the effect of bribery on firm innovation in the context of a business environment where red tape and corruption are perceivably widespread. Specifically, we test the hypothesis that bribery undermines firm innovation using firm-level data of small and medium firms in Vietnam. Campbell and Thomas (2019) reported that about two thirds of respondents in their survey in Vietnam declared that they have bribed. Although Nguyen (2020) showed new evidence supporting the sand-thewheels hypothesis that bribery impedes firm revenue and labor productivity growth by using the dataset of small and medium firms in Vietnam, the research has not yet explored through which channel bribery affects firm performance. This paper manages to extend that study to investigate whether bribery negatively affect firm innovation. We speculate that the effect of bribery on firm performance may be partially mediated through firm innovation. We define innovation as a binary variable which takes the value of unity if the firm has introduced new products, new production processes, technologies or improved existing ones in the last two years. Given the binary nature of the dependent variable, a simple binary regression, such as a probit regression model, may be relevant.

However, there is a potential endogeneity problem in the model since innovation may reversely affect firm bribing behavior. Innovative firms may be more likely victims of corrupt public officials since they appear more profitable (Ayyagari et al., 2014) and may have to involve numerous bureaucratic procedures in launching new products or production processes. If endogeneity exists, simple binary regression estimators would give biased and inefficient results. To go around this potential endogeneity, we follow the literature by applying the Fisman and Svensson (2007) procedure to instrument the bribery variable with provincesector average probability of bribery. Another complication arises as the instrumental probit model can only handle continuous endogenous explanatory variables. As both the dependent variable and the endogenous explanatory variable are binary in our case, linear instrumental estimation would be biased. We, therefore, follow Wooldridge (2010) to take the advantage of the bivariate probit model, which produces efficient estimates for the probit model with binary endogenous explanatory variable. To be on the safe side, both simple probit regression and bivariate probit regression are employed. A Hausman-like likelihood ratio test is conducted to test the existence of endogeneity.

The rest of the study is structured as follows. In Section 2 , we briefly review the literature on the relationship between bribery and firm innovation. Section 3 presents our research methodology and gives a short description of our dataset. Section 4 reports estimation results and discusses findings. The last section is the conclusion.

\section{Literature Review}

The literature about the effect of bribery on firm innovation is relatively limited (Habiyaremye \& Raymond, 2018; Krammer, 2019). Nonetheless, the relationship between bribery and innovation has been often examined in the broader context of the relationship between bribery and firm performance. The orthodox view, usually referred to as the sand-the-wheels hypothesis, states that bribery is detrimental to firm performance (De Rosa, Nishaal, \& Holger, 2015; Fisman \& Svensson, 2007; Gaviria, 2002). One of the underlying arguments is that bribery undermines firm investment and innovation and triggers rent-seeking behaviors (Asiedu \& Freeman, 2009; Dal Bó \& Rossi, 2007; Méon \& Sekkat, 2005; Murphy, Shleifer, \& Vishny, 1991; O'Toole \& Tarp, 2014).

Bribery may undermine innovation in several mechanisms. First, it may increase transaction costs and uncertainty involving innovation processes which hinder firms from engaging in innovation (Luo, 2005). Second, bribery may deteriorate new business formation and market competition, which is necessary for firm innovation to flourish. Aidis, Estrin, and Mickiewicz (2012) claimed that innovation is nurtured by new business entry. They argued that business entry may face with bureaucratic barriers in a corrupt business environment, which depresses entrepreneurship. The third possible way of influence is that the existence of bribery weakens the institutional trust necessary for innovation and firm long-term development (Habiyaremye \& Raymond, 2018). Veracierto (2008) constructed a game-based model to show that corruption control has a positive effect on product innovation. Mahagaonkar (2010) conducted a firmlevel analysis with firms in Africa and found that corruption negatively influences product innovation and organizational innovation but encourages marketing innovation. Corruption seems not to affect process innovation, however.

On the contrary, some authors argued that bribery may facilitate firm performance since it could help to get things done (Dreher \& Gassebner, 2013; Mendoza, Lim, \& Lopez, 2015; Radaev, 2004). There are several channels that bribery may help innovation. First, bribery can reduce transaction costs involving innovative activities such as introducing new products. In corrupt economies, innovative firms may face with numerous procedures to obtain permits, licenses or approvals in order to implement their innovations (D'Este, Iammarino, Savona, \& von Tunzelmann, 2012; Hadjimanolis, 1999). Firms can overcome such procedures and poor public services by paying bribes (Bertrand, Djankov, Hanna, \& Mullainathan, 2007; Hunt \& Laszlo, 2012). Leff (1964) stressed that corruption can serve as an instrument to hedge against political risk and thus help firm investment. Second, firms may pay bribes to avoid penalties from corrupt public officials. Ahlin and Bose (2007) showed that firms may face 
delays in receiving licenses or may never get licenses since bribing firms may go on faster track ahead of them.

Galang (2012), in a survey of literature on the relationship between government corruption and firm performance, pointed out that firms that refused to bribe may be penalized by bureaucratic obstacles. Lastly, bribery would help to build long-term relationships with public officials which may give certain advantages to firms (Leff, 1964). Since innovation involves interaction with public officials, long-term ties may secure firms in dealing with the bureaucracy. Some empirical evidences have been found to support this view. For example, Krammer (2019) examined the effect of bribery on new product introduction of firms in emerging markets. He argued that bribery may help innovative firms by clearing bureaucratic obstacles, compensating for the lack of kinship, and hedging against political risks. His empirical analysis provided support to the argument. Xia, Tan, and Bai (2018) demonstrated that corruption, measured by informal payments, increases the probability of innovation. However, they found that, the gender of firm managers may matter. Particularly, they explored that female managers may weaken the link between corruption and innovation and therefore, firms with female managers are less likely to engage in bribery.

In short, it is still indeterminate about how bribery affects firm innovation. Additional studies are much needed to shed light on the relationship.

\section{Research Methods and Materials}

In this study, we attempt to test the hypothesis that bribery depresses firm innovation using firm-level survey data of small and medium firms in Vietnam. Innovation is often defined in the literature to include one, or some combinations or all of the following: introduction of new products, new production processes, new technologies or the improvement of existing ones (Aujirpongpan \& Hareebin, 2020; Habiyaremye \& Raymond, 2018; Krammer, 2019; Lederman, 2010). Given the binary nature of the innovation variable, the relationship between bribery and firm innovation can be estimated using a simple probit regression model as follow:

$$
\text { Innovation }=1[X \beta+\alpha \text { Bribery }+u>0]
$$

where Innovation is a binary variable, $X$ is a vector of exogenous explanatory variables and Bribery is a binary variable which is one if a firm engages in bribing behavior, $\beta$ is a vector of coefficients, $\alpha$ is the coefficient associated with the bribery variable, and $\mathrm{u}$ is the error term assumed to be normally distributed.

If the bribery variable is exogenous, the estimation of the above model is straightforward. The estimation of the probit model in equation (1) would, however, result in biased estimates if it is an endogenous explanatory variable. A considerable literature suggests that firm performance, including firm innovation, may reversely influence its bribing behavior. For example, Ayyagari et al. (2014) showed that innovators pay more bribe than non-innovators across 25,000 firms in 57 countries. Clarke and Xu (2004) found that the more profitable a firm, the more likely it pays bribe. Bai, Jayachandran, Malesky, and Olken (2019) proved that firm growth reduce bribery since it increases firm refusal power. As innovation is likely to correlate with firm growth and other indicators of firm performance, it may influence a firm's decision to pay bribe.

The usual approach in dealing with endogeneity problem is to use an instrumental variable. A valid instrument must be correlated with the endogenous explanatory variable but uncorrelated with the dependent variable. Suppose that we can find an instrumental variable $\mathrm{z}$ that meets the above conditions such that:

$$
\text { Bribery }=1[X \delta+z \gamma+v>0]
$$

where $X$ is the same vector of exogenous variables as in equation (1); $\delta$ is the vector of coefficients, $\gamma$ is the coefficient of the instrumental $z$; and $v$ is a normally distributed error term. Combining equation (1) and equation (2), our model with endogenous bribery variable becomes:

$$
\begin{aligned}
& \text { Innovation }=1[X \beta+\alpha \text { Bribery }+u>0] \\
& \text { Bribery }=1[X \delta+z \gamma+v>0]
\end{aligned}
$$

Since the dependent variable Innovation is binary, the model in equations (3) cannot be estimated using instrumental linear regression techniques. An instrumental probit regression is in order if the endogenous explanatory variable was continuous. A complication arises in our case as both the dependent variable and the endogenous explanatory variable in our model are binary. The application of instrumental regression techniques above may, therefore, produce biased and inefficient estimates, which is often referred to as forbidden regressions. Fortunately, Wooldridge (2010) suggests that we can take the advantage of a bivariate probit model with maximum likelihood estimator to obtain unbiased and efficient estimates of the binary model with an endogenous binary explanatory variable. The bivariate probit model takes the form:

$$
\begin{aligned}
& y_{1}=1\left[X_{1} \beta_{1}+e_{1}>0\right] \\
& y_{2}=1\left[X_{2} \beta_{2}+e_{2}>0\right]
\end{aligned}
$$


where $X_{1}$ and $X_{2}$ are $\left(\begin{array}{lll}1 & x & K_{1}\end{array}\right)$ and $\left(\begin{array}{lll}1 & x & K_{2}\end{array}\right)$ vectors of explanatory variables respectively; $\beta_{1}$ and $\beta_{2}$ are vectors of coefficients; $e_{1}$ and $e_{2}$ are error terms. These error terms are assumed to be independent of $\left(X_{1}, X_{2}\right)$ and follow a bivariate normal distribution. Wooldridge (2010)including models with dynamics and/or individual heterogeneity. In addition to general estimation frameworks (particularly methods of moments and maximum likelihood argued that the form of the joint conditional density function of the bivariate probit model is unchanged whether or not $y_{2}$ is included in $X_{1}$. This property allows us to employ the bivariate probit framework to estimate the binary model with an endogenous binary explanatory variable. Clearly, if we replace $X_{1} \beta_{1}$ and $X_{2} \beta_{2}$ in equations (4) with $X \beta+\alpha$ Bribery and $X \delta+z \gamma$ respectively, the bivariate probit model in equations (4) becomes the binary model with an endogenous binary explanatory variable in equations (3).

To stay on the safe side and for comparison purpose, we estimate both the simple probit model in equation (1) and the bivariate probit model in equations (3). Further, we also test the existence of endogeneity in the models. Traditionally, to identify the existence of endogeneity, a Hausman endogeneity test can be performed. The underlying assumptions of the Hausman test are, however, rather demanding which are not met in our case (the Hausman test in STATA 15.0 gives negative chi-square test statistics, indicating that the Hausman test cannot be used). We, thus, opt for the Hausman-like likelihood ratio test to test the correlation between the error terms in the bivariate probit model. Knapp and Seaks (1998) proved that the likelihood ratio test in the bivariate probit model can serve as the new Hausman test of endogeneity for the probit model with a binary explanatory variable.

The above models are estimated using firm-level data from 2,637 small and medium firms in Vietnam. The data were collected in 2015 in nine provinces across the country, based on face-to-face interviews with firm owners or managers. The firms were sampled in approximately 18 sectors such as food processing, fabricated metal products, and wood product manufacturing. Given the relatively large number of observations, it is likely that the error terms satisfy the normality conditions of the simple probit model and bivariate probit model. We define innovation as a binary variable which is unity if a firm has introduced new products, new technologies or production processes or has improved existing ones in the past two years. This definition of innovation differs somewhat from some other authors. Krammer (2019)its consequences for firms are less understood. This study examines the effect of bribery on the innovative performance of firms in emerging markets as reflected by new product introductions. I argue that bribery may help innovators in these markets to introduce new products by overcoming bureaucratic obstacles, compensating for the lack of kinship or political affiliations, and hedging against political risk. I also propose that the relationship between firm bribery and new product introduction will be negatively moderated (i.e., weakened, for example, focused solely on the firm's introduction of new products. We believe that our approach to defining the innovation variable is more holistic since innovation can take different forms at different stages of firm product and production process development. The key explanatory variable is bribery, which is also a binary variable.

Bribery is one if a firm pays bribe and zero otherwise. As the variable is potentially endogenous, in the bivariate probit model, we follow Fisman and Svensson (2007) to instrument bribery variable with the province-sector average of bribery probability. This instrument has been widely applied in the literature its consequences for firms are less understood. This study examines the effect of bribery on the innovative performance of firms in emerging markets as reflected by new product introductions. I argue that bribery may help innovators in these markets to introduce new products by overcoming bureaucratic obstacles, compensating for the lack of kinship or political affiliations, and hedging against political risk. I also propose that the relationship between firm bribery and new product introduction will be negatively moderated (i.e., weakened(Krammer, 2019; Waldemar, 2012) its consequences for firms are less understood. This study examines the effect of bribery on the innovative performance of firms in emerging markets as reflected by new product introductions. I argue that bribery may help innovators in these markets to introduce new products by overcoming bureaucratic obstacles, compensating for the lack of kinship or political affiliations, and hedging against political risk. I also propose that the relationship between firm bribery and new product introduction will be negatively moderated (i.e., weakened. Other exogenous explanatory variables include firm characteristic variables, owner/manager characteristic variables and a variable of business competition condition. For the sake of comparison and reference, we retain a similar set of explanatory variables as in Nguyen (2020). These variables may influence firm performance in general and firm innovation in particular. For instance, firm total assets may influence firm innovation since larger firms may have more resources and capabilities to innovate.

Following Krammer (2019)its consequences for firms are less understood. This study examines the effect of bribery on the innovative performance of firms in emerging markets as reflected by new product introductions. I argue that bribery may help innovators in these markets to introduce new products by overcoming bureaucratic obstacles, compensating for the lack of kinship or political affiliations, and hedging against political risk. I also propose that the relationship 
between firm bribery and new product introduction will be negatively moderated (i.e., weakened, we add three new explanatory variables that may affect firm innovation. The first one is the exporter binary variable. Golovko and Valentini (2011)we advance and test the idea that innovation and export are complementary strategies for SMEs' growth. We argue that innovation and export positively reinforce each other in a dynamic virtuous circle, and we identify and describe the process through which this complementarity relationship takes place. Participating in export markets

Table 1: List of dependent and independent variables

\begin{tabular}{|c|c|}
\hline Variable & Description \\
\hline \multicolumn{2}{|l|}{ Dependent variable } \\
\hline Innovation & $\begin{array}{l}\text { Binary variable which is one if a } \\
\text { firm has introduced new products, } \\
\text { technologies or production processes } \\
\text { or has improved existing ones in the } \\
\text { last two years }\end{array}$ \\
\hline \multicolumn{2}{|c|}{ Explanatory variables } \\
\hline Bribery & $\begin{array}{l}\text { Dummy variable which is one if a firm } \\
\text { pays bribe. }\end{array}$ \\
\hline Total assets & $\begin{array}{l}\text { Total assets of firm in logarithm which } \\
\text { proxies firm size. }\end{array}$ \\
\hline Firm age & $\begin{array}{l}\text { Logarithms of the number of years } \\
\text { since the firm established. }\end{array}$ \\
\hline Household firm & $\begin{array}{l}\text { Binary variable which is one if the } \\
\text { firm is run by a household. }\end{array}$ \\
\hline $\begin{array}{l}\text { Increasing } \\
\text { competition }\end{array}$ & $\begin{array}{l}\text { Dummy variable which is one if the } \\
\text { firm faces with increasing competition }\end{array}$ \\
\hline Single owner & $\begin{array}{l}\text { Binary variable which is one if the } \\
\text { firm has a single owner. }\end{array}$ \\
\hline $\begin{array}{l}\text { Age of firm owner } \\
\text { or manager }\end{array}$ & $\begin{array}{l}\text { Logarithms of the age of owner or } \\
\text { manager in years. }\end{array}$ \\
\hline $\begin{array}{l}\text { Gender of firm } \\
\text { owner or manager }\end{array}$ & Binary variable which is one for male. \\
\hline Primary education & $\begin{array}{l}\text { Binary variable if firm owner or } \\
\text { manager's general education is } \\
\text { primary education or below. }\end{array}$ \\
\hline $\begin{array}{l}\text { Professional } \\
\text { education }\end{array}$ & $\begin{array}{l}\text { Binary variable if firm owner or } \\
\text { manager's professional education is } \\
\text { vocational college or above. }\end{array}$ \\
\hline Exporter & $\begin{array}{l}\text { Binary variable which is one if the } \\
\text { firm has export sale. }\end{array}$ \\
\hline $\begin{array}{l}\text { Share of } \\
\text { professional staff }\end{array}$ & $\begin{array}{l}\text { The share in percentage of } \\
\text { firm professional staff including } \\
\text { managerial one }\end{array}$ \\
\hline $\begin{array}{l}\text { Managerial } \\
\text { experience }\end{array}$ & $\begin{array}{l}\text { Binary variable which is one if firm } \\
\text { owner or manager has previous } \\
\text { experience in firm products. }\end{array}$ \\
\hline
\end{tabular}

can promote firms' learning, and thus enhance innovation performance. At the same time, through innovation, firms can enter new geographical markets with novel and better products, therefore making exports more successful, and, by the same token, they can also improve the quality and consequently increase the sales - of the products sold domestically. We test our theory using an unbalanced panel of Spanish manufacturing firms over the period 1990-1999. We find robust empirical support for our hypothesis: consistent with the presence of complementarity, we show that the positive effect of innovation activity on firms' growth rate is higher for firms that also engage in exports, and vice versa. Furthermore, we show that, Ceteris paribus, firms' adoption of one growth strategy (e.g., entering export markets showed that exportation can promote firm learning and innovating process. The second variable is the share of professional employees in the firm, including managerial ones. It is argued that innovation within firms is almost done by professional staff. The last variable is the prior experience of firm owners or managers with respect to firm products. Holcomb, Holmes, and Connelly (2009) found that managerial experience positively affects firm value-creation. Firm owner/manager experience is captured by a binary variable which is one if the owner/manager has previously worked with firm products before founding or joining the firm. The models are estimated using STATA 15.0 statistical package. The list of variables and their brief definitions are given in Table 1.

\section{Results and Discussion}

\subsection{Descriptive Statistics}

Out of 2,637 firms in our data, 905 firms are innovators. Particularly, 628 firms have introduced new products; 353 firms have made improvements in existing product lines; and 129 firms have adopted new technologies or new production processes in the last two years. Before examining the estimation results, we demonstrate some descriptive statistics of the variables used in our models, which highlight certain characteristics of innovative and non-innovative firms.

Table 2 reports the proportions of innovative and noninnovative firms in different dimensions. We perform Koopman (1984) proportion test on the difference in proportions between innovative firms and non-innovative firms. It appears that the proportions of bribing firms are not significantly different between innovative and non-innovative firms. About 43 percent of firms in both groups have involved in bribing behaviors. The proportion of firms run by a household is significantly higher in the non-innovative group with 66.1 percent, compared with 56.6 percent in the innovative group. Education and professional attainment of firm owners/ managers are also significantly higher among innovators. Interestingly, owners or managers of innovative 
firms are less likely to have prior experience with firm products. Only 5.3 percent of firm owners/managers had previously worked with similar products before establishing or joining the firms. The corresponding proportion of noninnovative firms is 18.4 percent. Innovative firms are also more likely to face with increasing competition (56 percent compared with 53.3 percent). The ratio of exporters is also higher among innovative firms.

Table 3 demonstrates the mean and standard deviation of the continuous variables used in our models. We perform the usual t-test of the mean difference between the innovative and non-innovative firms. As we can see, innovative firms tend

Table 2: Descriptive statistics of binary variables

\begin{tabular}{|l|c|c|}
\hline \multirow{2}{*}{\multicolumn{1}{|c|}{ Variable }} & \multicolumn{2}{c|}{ Proportion (\%) } \\
\cline { 2 - 3 } & $\begin{array}{c}\text { Innovative } \\
\text { firms } \\
(\mathbf{N}=905)\end{array}$ & $\begin{array}{c}\text { Non-innovative } \\
\text { firms (N=1,732) }\end{array}$ \\
\hline Bribery & 43.9 & 42.7 \\
\hline Household firm & $56.6^{* * *}$ & $66.1^{* * *}$ \\
\hline $\begin{array}{l}\text { Gender of owner/ } \\
\text { manager (male =1) }\end{array}$ & 59.4 & 58.8 \\
\hline Single owner & $83.8^{* * *}$ & $87.6^{* * *}$ \\
\hline Primary education & $4.9^{* *}$ & $7.4^{* *}$ \\
\hline Professional education & $30.5^{* * *}$ & $25.2^{* * *}$ \\
\hline Increasing competition & $56.0^{*}$ & $53.3^{*}$ \\
\hline Exporter & $10.4^{* * *}$ & $5.2^{* * *}$ \\
\hline $\begin{array}{l}\text { Owner/manager } \\
\text { experience }\end{array}$ & $5.3^{* * *}$ & $18.4^{* * *}$ \\
\hline
\end{tabular}

$* * *,{ }^{* *}$ : One and five percent statistically significant levels respectively.

Table 3: Descriptive statistics of continuous variables

\begin{tabular}{|l|c|c|c|c|}
\hline \multirow{2}{*}{ Variable } & \multicolumn{2}{|c|}{$\begin{array}{c}\text { Innovative firms } \\
\mathbf{N}=905\end{array}$} & \multicolumn{2}{c|}{$\begin{array}{c}\text { Non-innovative } \\
\text { firms } \\
\mathbf{N}=1,732\end{array}$} \\
\cline { 2 - 5 } & Mean & $\begin{array}{c}\text { Standard } \\
\text { Dev }\end{array}$ & Mean & $\begin{array}{c}\text { Standard } \\
\text { Dev }\end{array}$ \\
\hline Total assets & $14.3^{* * *}$ & 1.9 & $13.9^{* * *}$ & 1.7 \\
\hline Firm age & $2.6^{* *}$ & 0.6 & $2.5^{* *}$ & 0.8 \\
\hline $\begin{array}{l}\text { Age of } \\
\text { owner or } \\
\text { manager }\end{array}$ & 3.8 & 0.3 & 3.8 & 0.2 \\
\hline $\begin{array}{l}\text { Share of } \\
\text { professional } \\
\text { staff }\end{array}$ & $36.6^{*}$ & 25.3 & $38.4^{*}$ & 24.6 \\
\hline
\end{tabular}

***, ${ }^{* *}, *$ : One, five and ten percent statistically significant levels respectively. to be larger and older. However, contrary to our expectation, the average share of professional staff is, on average, lower in innovative firms, though the difference is only significant at ten-percent level. The age of firm owners and managers does not appear to be different across the groups.

Table 4 presents the estimation results of the simple probit model and the bivariate probit model. In both models, we report the coefficients of the log-odd equations and the average marginal effects, which measure the effects of changes in explanatory variables on the binary dependent variable. At the first glance, we can see that the results are not considerably different between the two models, including the sign and the magnitude of estimated coefficients and marginal effects, and the significant levels. The table shows that in the case of small and medium firms in Vietnam, bribery significantly hurts firm innovation. The marginal effect of the bribery variable in the simple probit model is -0.06 , that means the probability of innovating in bribing firms is 0.06 point lower than non-bribing firms. The effect is even twice as large in the bivariate probit model. Firm size also matters. Larger firms are more likely to innovate as expected. The marginal effects of firm total assets on innovation are the same in the two models. Firms run by households tend to be significantly less innovative. The marginal effects of the variable on firm innovation are also similar in the two models. Firms that export their products to international markets are more likely to innovate as well. It is interesting to observe that firms with owners or managers that have previous experience in firm products appear less innovative than firms without such kind of owners/managers. Other explanatory variables do not seem to be statistically significant in explaining the probability of innovation. Surprisingly, the share of professional staff in total employees of firms has an insignificant effect on firm innovation. The increasing competition also does not influence firm innovation as we expect.

To test for the presence of endogeneity in the models, we conduct the Hausman-like likelihood ratio test, the result of which is presented at the bottom of Table 4. The null hypothesis is that there is no endogeneity in the models. As reported in the table, the chi-square statistics is 0.97 and the $\mathrm{p}$-value is 0.33 . The test statistics show that we cannot reject the null hypothesis of no endogeneity. In other words, bribery may not be an endogenous variable in this case. The test result explains why we have similar results in the two models.

Our findings support the hypothesis that bribery undermines innovation even in the context of a perceptible corrupt business environment. Bribery may reduce firm motivation to innovate since they can rely on bribery to gain certain advantages. Bribing firms may find it easier to engage in rent-seeking behaviors rather than spending resources on the probably riskier process of innovation. It is likely that innovation plays partially as a mediating factor in channeling 
the impact of bribery on firm revenue and labor productivity growth. As bribery hampers firm innovation, long-term firm competitiveness and growth would be eroded.

Our results complement the findings in Nguyen (2020). Using the same dataset, Nguyen (2020) showed that bribing behaviors negatively affect firm performance. He also found that household firms tend to have lower labor productivity growth. Our results show that these factors also influence

Table 4: Estimation Results of Simple Probit Model and Bivariate Probit Model

\begin{tabular}{|c|c|c|c|c|}
\hline \multirow[t]{2}{*}{ Variable } & \multicolumn{2}{|c|}{$\begin{array}{l}\text { Simple probit } \\
\text { model }\end{array}$} & \multicolumn{2}{|c|}{$\begin{array}{c}\text { Bivariate probit } \\
\text { model }\end{array}$} \\
\hline & Coeffa & $\mathrm{ME}^{\mathrm{b}}$ & Coeffa & $\mathrm{ME}^{\mathrm{b}}$ \\
\hline Bribery & $-0.18^{* * *}$ & $-0.06^{* * *}$ & $-0.35^{*}$ & $-0.12^{*}$ \\
\hline Total assets & $0.05^{* *}$ & $0.02^{* *}$ & $0.06^{* * *}$ & $0.02^{* * *}$ \\
\hline Firm age & 0.04 & 0.01 & 0.03 & 0.01 \\
\hline $\begin{array}{l}\text { Household } \\
\text { firm }\end{array}$ & $-0.24^{* * *}$ & $-0.08^{* * *}$ & $-0.27^{* * *}$ & $-0.09^{* * *}$ \\
\hline $\begin{array}{l}\text { Increasing } \\
\text { competition }\end{array}$ & 0.07 & 0.03 & 0.08 & 0.03 \\
\hline Single owner & 0.04 & 0.01 & 0.03 & 0.01 \\
\hline $\begin{array}{l}\text { Age of } \\
\text { owner/ } \\
\text { manager }\end{array}$ & -0.09 & -0.03 & -0.09 & -0.03 \\
\hline $\begin{array}{l}\text { Gender } \\
\text { of owner/ } \\
\text { manager }\end{array}$ & 0.09 & 0.03 & 0.09 & 0.03 \\
\hline $\begin{array}{l}\text { Primary } \\
\text { education }\end{array}$ & -0.14 & -0.05 & -0.14 & -0.05 \\
\hline $\begin{array}{l}\text { Professional } \\
\text { education }\end{array}$ & -0.07 & -0.03 & -0.07 & -0.02 \\
\hline Exporter & $0.34^{* * *}$ & $0.12^{* * *}$ & $0.34^{* \star *}$ & $0.12^{* * *}$ \\
\hline $\begin{array}{l}\text { Owner/ } \\
\text { manager } \\
\text { experience }\end{array}$ & $-0.78^{* * *}$ & $-0.27^{* * *}$ & $-0.79^{* * *}$ & $-0.27^{* * *}$ \\
\hline $\begin{array}{l}\text { Ratio of } \\
\text { professional } \\
\text { workers }\end{array}$ & 0.17 & 0.06 & 0.14 & 0.05 \\
\hline Constant & -0.76 & & -0.8 & \\
\hline $\begin{array}{l}\text { Hausman- } \\
\text { like } \\
\text { likelihood } \\
\text { ratio test of } \\
\text { endogeneity }\end{array}$ & \multicolumn{2}{|c|}{$\begin{array}{l}\text { Null hypothesis: } \\
\text { no endogeneity } \\
(\text { rho }=0)\end{array}$} & $\begin{array}{l}\text { Chi- } \\
\text { square } \\
\text { statistics: } \\
0.97\end{array}$ & Prob: 0.33 \\
\hline
\end{tabular}

a: Coefficient; b: Marginal Effect

***, *: $1 \%$ and $10 \%$ statistically significant levels, respectively. firm innovation. Larger firms may have more resources to innovate. Household firms may rely more on experience and family know-how that may discourage them from innovation. The legacy of the past may hinder firm innovation. That may explain why we find that owners/managers with prior experience seem to negatively influence firm innovation. On the contrary, exporters must be more innovative since they face with competition challenges and more demanding customers in international markets. We find that education and professional training of firm owners/managers have an insignificant impact on firm innovation. That may reflect the characteristics of small and medium firms in Vietnam, where most firm owners/managers have accumulated their knowledge from learning by doing rather than from official training and education.

\section{Conclusions}

In this study, we aim to extend the literature on the effect of bribery on firm performance by empirically analyze the effect of bribery on firm innovation. We estimate simultaneously a simple probit regression and a bivariate probit model with the binary variable of innovation as a dependent variable. Our results show that the presence of bribery significantly lowers the firm's probability to innovate. Firm size also matters in explaining its innovation. Firms run by households tend to be less innovative than other firms. We find that exporters are more likely to innovate, and that prior experience of firm owners/managers negatively affects firm innovation. Our finding contributes new empirical evidence to the limited literature on bribery and firm innovation relationship. The finding supports the orthodox view that bribery hurts firm performance and innovation can play a role in the mediating mechanism.

\section{References}

Ahlin, C., \& Bose, P. (2007). Bribery, inefficiency, and bureaucratic delay. Journal of Development Economics, 84(1), 465-486. https://doi.org/10/fg5k59

Aidis, R., Estrin, S., \& Mickiewicz, T. M. (2012). Size matters: Entrepreneurial entry and government. Small Business Economics, 39(1), 119-139. https://doi.org/10/cm5frq

Asiedu, E., \& Freeman, J. (2009). The Effect of Corruption on Investment Growth: Evidence from Firms in Latin America, SubSaharan Africa, and Transition Countries*. Review of Development Economics, 13(2), 200-214. https://doi.org/10/d5sb8p

Audretsch, D. B. (1995). Innovation, growth and survival. International Journal of Industrial Organization, 13(4), 441457. https://doi.org/10/bsxm7k

Aujirpongpan, S., \& Hareebin, Y. (2020). The Effect of Strategic Intuition, Business Analytic, Networking Capabilities and Dynamic Strategy on Innovation Performance: The Empirical 
Study Thai Processed Food Exporters. Journal of Asian Finance, Economics and Business, 7(1), 259-268. https:/ /doi.org/10.13106/jafeb.2020.vol7.no1.259

Ayyagari, M., Demirgüç-Kunt, A., \& Maksimovic, V. (2014). Bribe Payments and Innovation in Developing Countries: Are Innovating Firms Disproportionately Affected? Journal of Financial and Quantitative Analysis, 49(1), 51-75. https:// doi.org/10/gc4jp3

Bai, J., Jayachandran, S., Malesky, E. J., \& Olken, B. A. (2019). Firm Growth and Corruption: Empirical Evidence from Vietnam. The Economic Journal, 129(618), 651-677. https:// doi.org/10/gfzt7b

Bertrand, M., Djankov, S., Hanna, R., \& Mullainathan, S. (2007). Obtaining a Driver's License in India: An Experimental Approach to Studying Corruption. The Quarterly Journal of Economics, 122(4), 1639-1676. https://doi.org/10/cjptzz

Campbell, L., \& Thomas, A. (2019). People's Experiences of Corruption: Implications for Business in South-East Asia. Retrieved from http://files.transparency.org/content/ download/2411/14666/file/2019_Report_\%20ExperiencesCorr uptionImplicationsBusinessSouth-EastAsia_English.pdf

Chiu, S.-H., \& Lin, T.-Y. (2019). Evaluation of Regional Knowledge Innovation System in China: An Economic Framework Based on Dynamic Slacks-based Approach. Journal of Asian Finance, Economics and Business, 6(3), 141-149. https:// doi.org/10.13106/jafeb.2019.vol6.no3.141

Clarke, G. R. G., \& Xu, L. C. (2004). Privatization, competition, and corruption: How characteristics of bribe takers and payers affect bribes to utilities. Journal of Public Economics, 88(9), 2067-2097. https://doi.org/10/bpf9d9

Dal Bó, E., \& Rossi, M. A. (2007). Corruption and inefficiency: Theory and evidence from electric utilities. Journal of Public Economics, 91(5), 939-962. https://doi.org/10/b23bjm

De Rosa, D., Nishaal, G., \& Holger, G. (2015). Corruption and Productivity: Firm-level Evidence. Journal of Economics and Statistics (Jahrbuecher Fuer Nationaloekonomie Und Statistik), 235(2), 115-138.

D’Este, P., Iammarino, S., Savona, M., \& von Tunzelmann, N. (2012). What hampers innovation? Revealed barriers versus deterring barriers. Research Policy, 41(2), 482-488. https://doi. org/10/cwzcxk

Dreher, A., \& Gassebner, M. (2013). Greasing the wheels? The impact of regulations and corruption on firm entry. Public Choice, 155(3), 413-432. https://doi.org/10/cw54zp

Fisman, R., \& Svensson, J. (2007). Are corruption and taxation really harmful to growth? Firm level evidence. Journal of Development Economics, 63-75. https://doi.org/10/cnvgz8

Galang, R. M. N. (2012). Victim or Victimizer: Firm Responses to Government Corruption. Journal of Management Studies, 49(2), 429-462. https://doi.org/10/c94bq6

Gaviria, A. (2002). Assessing the effects of corruption and crime on firm performance: Evidence from Latin America. Emerging Markets Review, 3(3), 245-268. https://doi.org/10/bqj9zm
Golovko, E., \& Valentini, G. (2011). Exploring the complementarity between innovation and export for SMEs' growth. Journal of International Business Studies, 42(3), 362-380. https://doi. org $/ 10 /$ dj9wtb

Habiyaremye, A., \& Raymond, W. (2018). How do foreign firms' corruption practices affect innovation performance in host countries? Industry-level evidence from transition economies. Innovation, 20(1), 18-41. https://doi.org/10/ggmhgw

Hadjimanolis, A. (1999). Barriers to innovation for SMEs in a small less developed country (Cyprus). Technovation, 19(9), 561-570. https://doi.org/10/c4cthh

Holcomb, T. R., Holmes, R. M. Jr., \& Connelly, B. L. (2009). Making the most of what you have: Managerial ability as a source of resource value creation. Strategic Management Journal, 30(5), 457-485. https://doi.org/10/d45hxg

Hunt, J., \& Laszlo, S. (2012). Is Bribery Really Regressive? Bribery's Costs, Benefits, and Mechanisms. World Development, 40(2), 355-372. https://doi.org/10/fg3jgb

James, S. D., Leiblein, M. J., \& Lu, S. (2013). How Firms Capture Value From Their Innovations. Journal of Management, 39(5), 1123-1155. https://doi.org/10/gf2zpg

Knapp, L. G., \& Seaks, T. G. (1998). A Hausman test for a dummy variable in probit. Applied Economics Letters, 5(5), 321-323. https://doi.org/10/d3qxq5

Koopman, P. A. R. (1984). Confidence Intervals for the Ratio of Two Binomial Proportions. Biometrics, 40(2), 513-517. https:// doi.org/10/d25kfj

Krammer, S. M. S. (2019). Greasing the Wheels of Change: Bribery, Institutions, and New Product Introductions in Emerging Markets. Journal of Management, 45(5), 1889-1926. https:// doi.org/10/gcwbnz

Lederman, D. (2010). An international multilevel analysis of product innovation. Journal of International Business Studies, 41(4), 606-619. https://doi.org/10/bjk9j4

Leff, N. H. (1964). Economic Development Through Bureaucratic Corruption. American Behavioral Scientist, 8(3), 8-14. https:// doi.org/10/dxvet6

Luo, Y. (2005). An Organizational Perspective of Corruption1. Management and Organization Review, 1(1), 119-154. https:// doi.org/10/bhq7tr

Mahagaonkar, P. (2010). Money and Ideas: Four Studies on Finance, Innovation and the Business Life Cycle. https://doi. org/10.1007/978-1-4419-1228-2

Mendoza, R. U., Lim, R. A., \& Lopez, A. O. (2015). Grease or Sand in the Wheels of Commerce? Firm Level Evidence on Corruption and SMES. Journal of International Development, 27(4), 415-439. https://doi.org/10/ggjpcx

Méon, P.-G., \& Sekkat, K. (2005). Does corruption grease or sand the wheels of growth? Public Choice, 122(1), 69-97. https:// doi.org/10/c2jghb

Murphy, K. M., Shleifer, A., \& Vishny, R. W. (1991). The Allocation of Talent: Implications for Growth. The Quarterly Journal of Economics, 106(2), 503-530. https://doi.org/10/fwv996 
Nguyen, N. A., Doan, Q. H., Nguyen, N. M., \& Tran-Nam, B. (2016). The impact of petty corruption on firm innovation in Vietnam. Crime, Law and Social Change, 65(4), 377-394. https://doi.org/10/f8rkpt

Nguyen, T. N. (2020). Does Bribery Sand the Wheels? New Evidence from Small and Medium Firms in Vietnam. Journal of Asian Finance, Economics and Business, 7(4), [In Press].

O’Toole, C. M., \& Tarp, F. (2014). Corruption and the Efficiency of Capital Investment in Developing Countries. Journal of International Development, 26(5), 567-597. https://doi.org/10/ f6bpm5

Radaev, V. (2004). How Trust is Established in Economic Relationships when Institutions and Individuals Are Not Trustworthy: The Case of Russia. In J. Kornai, B.
Rothstein \& S. Rose-Ackerman (Eds.), Creating Social Trust in Post-Socialist Transition (pp. 91-110). https://doi. org/10.1057/9781403980663_6

Veracierto, M. (2008). Corruption and innovation. Economic Perspectives, (qi), 29-39.

Waldemar, F. S. de. (2012). New Products and Corruption: Evidence from Indian Firms. The Developing Economies, 50(3), 268284. https://doi.org/10/ggmjh8

Wooldridge, J. M. (2010). Econometric Analysis of Cross Section and Panel Data. Cambridge, MA: The MIT Press.

Xia, H., Tan, Q., \& Bai, J. (2018). Corruption and Technological Innovation in Private Small-Medium Scale Companies: Does Female Top Management Play a Role? Sustainability, 10(7), 2252. https://doi.org/10/ggk6dv 
